Article

\title{
Mn/beta and Mn/ZSM-5 for the low-temperature selective catalytic reduction of NO with ammonia: Effect of manganese precursors
}

\author{
Wenjin Xua , Guangxu Zhang a,*, Hanwei Chen a, Guomeng Zhang b, Yang Han a, Yichuan Chang a, \\ Peng Gong a \\ a School of Chemistry, Chemical Engineering and Life Science, Wuhan University of Technology, Wuhan 430070, Hubei, China \\ b Shanghai Hengyuan Marine Equipment Co., Ltd., Shanghai 201709, China
}

\section{A R T I C L E I N F}

\section{Article history:}

Received 15 August 2017

Accepted 22 November 2017

Published 5 January 2018

\section{Keywords:}

$\mathrm{Mn} /$ beta

Mn/ZSM-5

Low-temperature

Catalytic performance

Selective catalytic reduction

Manganese precursors

\begin{abstract}
A B S T R A C T
Two series of Mn/beta and Mn/ZSM-5 catalysts were prepared to study the influence of how different Mn precursors, introduced to the respective parent zeolites by wet impregnation, affected the selective catalytic reduction (SCR) of $\mathrm{NO}$ by $\mathrm{NH}_{3}$ across a low reaction temperature window of 50-350 ${ }^{\circ} \mathrm{C}$. In this study, the catalysts were characterized using $\mathrm{N}_{2}$ adsorption/desorption, X-ray diffraction, X-ray fluorescence, $\mathrm{H}_{2}$ temperature-programmed reduction, $\mathrm{NH}_{3}$ temperature-programmed desorption and X-ray photoelectron spectroscopy. As the manganese chloride precursor only partially decomposed this primarily resulted in the formation of $\mathrm{MnCl}_{2}$ in addition to the presence of low levels of crystalline $\mathrm{Mn}_{3} \mathrm{O}_{4}$, which resulted in poor catalytic performance. However, the manganese nitrate precursor formed crystalline $\mathrm{MnO}_{2}$ as the major phase in addition to a minor presence of unconverted Mn-nitrate. Furthermore, manganese acetate resulted principally in a mixture of amorphous $\mathrm{Mn}_{2} \mathrm{O}_{3}$ and $\mathrm{MnO}_{2}$, and crystalline $\mathrm{Mn}_{3} \mathrm{O}_{4}$. From all the catalysts screened, the test performance data showed Mn/beta-Ac to exhibit the highest NO conversion (97.5\%) at 240 ${ }^{\circ} \mathrm{C}$, which remained $>90 \%$ across a temperature window of $220-350{ }^{\circ} \mathrm{C}$. The excellent catalytic performance was ascribed to the enrichment of highly dispersed $\mathrm{MnO}_{x}\left(\mathrm{Mn}_{2} \mathrm{O}_{3}\right.$ and $\left.\mathrm{MnO}_{2}\right)$ species that act as the active phase in the $\mathrm{NH}_{3}$-SCR process. Furthermore, together with a suitable amount of weakly acidic centers, higher concentration of surface manganese and a greater presence of surface labile oxygen groups, SCR performance was collectively enhanced at low temperature.
\end{abstract}

(C) 2018, Dalian Institute of Chemical Physics, Chinese Academy of Sciences. Published by Elsevier B.V. All rights reserved.

\section{Introduction}

Nitrogen oxides $\left(\mathrm{NO}_{x}\right)$ are significant atmospheric pollutants that have significant impact on both air quality and human health and that result from the burning of fossil fuels such as refined crude oil products (petrol and diesel) or solid coal, from cars, ships and industrial processes [1-3]. Selective catalytic reduction (SCR) of $\mathrm{NO}_{x}$ is reported to be an already feasible and mature process, which is widely applied to flue gas denitrifica- tion $[4,5]$. The SCR denitration catalyst is one of the key components in a SCR system, with typical commercial catalysts such as $\mathrm{V}_{2} \mathrm{O}_{5}-\mathrm{WO}_{3} / \mathrm{TiO}_{2}$ and $\mathrm{V}_{2} \mathrm{O}_{5}-\mathrm{MoO}_{3} / \mathrm{TiO}_{2}$ being employed as the active components in this system [6]. There are, however, some shortcomings related the aforementioned catalysts, for example, the narrow working temperature window $\left(300-400^{\circ} \mathrm{C}\right)$ and the toxic effect of $\mathrm{V}_{2} \mathrm{O}_{5}$. Hence, there has been a wealth of interdependent research focusing on developing new highly effective and environmentally friendly SCR catalysts

\footnotetext{
* Corresponding author. Tel: +86-13871467069; E-mail: zhanggx2002@163.com This work was supported by the National Science and Technology Program of China (CDGC01-KT16). DOI: 10.1016/S1872-2067(17)62983-8 | http://www.sciencedirect.com/science/journal/18722067 | Chin. J. Catal., Vol. 39 , No. 1, January 2018
} 
$[7,8]$.

Over the past few years, researchers have developed increasingly attractive and efficient SCR catalysts. Owing to the particular features, various transition metals ( $\mathrm{Cr}, \mathrm{Mn}, \mathrm{Fe}, \mathrm{Cu}$ and $\mathrm{Ce}$ ) have been studied as the active components for SCR catalysts $[9,10]$. In particular, manganese-based catalysts are a current hot topic of interest because of the multiple valences, labile oxygen and diversiform oxidation states of manganese $\left(\mathrm{Mn}_{3} \mathrm{O}_{4}, \mathrm{Mn}_{2} \mathrm{O}_{3}, \mathrm{MnO}_{2}, \mathrm{MnO}\right)[11,12]$. Mn-based supported catalysts have attracted significant attention with respect to the manganese precursor used. Hwang et al. [13] used manganese(II) nitrate, manganese(II) acetate and manganese(III) acetate to prepare $\mathrm{MnO}_{x} / \mathrm{TiO}_{2}$ catalysts through a sol-gel method, concluding that the catalysts synthesized with manganese acetate showed higher catalytic performance as a result of abundant $\mathrm{MnO}_{2}$ species and strong acid sites. Fang et al. [14] claimed that catalysts prepared from manganese acetate and manganese carbonate, containing $\mathrm{Mn}_{2} \mathrm{O}_{3}$ and $\mathrm{Mn}_{3} \mathrm{O}_{4}$, resulted in superior catalytic performance when compared with the corresponding catalysts prepared by manganese nitrate and manganese sulfate. However, Pena et al. [15] observed that catalysts prepared using manganese nitrate yielded $\mathrm{MnO}_{2}$ and displayed enhanced catalytic performance than the corresponding catalyst prepared with manganese acetate. There remains on-going debate over how catalytic activity is influenced by the active phase of Mn-based catalysts prepared with different precursors. Therefore, to elucidate the influence of Mn precursors it is of interest to further investigate SCR performance and surface $\mathrm{MnO}_{x}$ species over Mn-based catalysts.

Furthermore, $\mathrm{TiO}_{2}$ exhibits poor specific surface areas, which is thought to hinder the performance of Mn-based supported catalysts [16]. However, other supports that include transition metal oxides [17], carbon materials [18] and zeolites [19] have been widely used for the preparation of Mn-containing catalysts. Zeolites possess several advantageous characteristics such as large specific surface areas, unique pore structures and abundant acid sites, and are reported to be excellent catalyst supports $[2,20]$. Recent trends in zeolite-based catalysts have led to a proliferation of studies, such as $\mathrm{MnO}_{x} / \mathrm{ZSM}-5$ [21], $\mathrm{MnO}_{x} /$ beta [22], $\mathrm{MnO}_{x} / \mathrm{USY}$ [23] and $\mathrm{MnO}_{x} / \mathrm{SAPO}-34$ [24]. Among these catalysts, the ZSM-5 series of catalysts $[25,26]$ have attracted significant attention as alternative SCR catalysts. Additionally, there is significant research focus on metal-modified beta zeolite because of the superior hydrothermal stability reported in recent years. For example, Frey et al. [27] demonstrated that $\mathrm{Fe} /$ beta exhibited higher activity than Fe/ZSM-5 and Fe/ZSM-12 across a broad temperature window. Additionally, Corma et al. [28] reported a stable Cu-beta catalyst having SCR activity as high as that of $\mathrm{Cu} / \mathrm{ZSM}-5$. These studies suggest that beta zeolite has been regarded as a promising SCR catalyst support. Hitherto, significant efforts have focused on Mn/ZSM-5 in terms of preparation methods, calcination temperature and catalytic behavior $[16,29]$. Nevertheless, there are few reports offering insight into the SCR performance and physicochemical properties of Mn/beta; while, in addition, the influence of manganese precursors on $\mathrm{NH}_{3}$-SCR performance of Mn/ZSM-5 and Mn/beta remains unclear. Ac- cordingly, further studies are required to conduct systematic research on manganese-modified beta zeolite.

In this paper, different Mn precursors such as manganese nitrate, manganese acetate and manganese chloride were employed to prepare $\mathrm{Mn} / \mathrm{ZSM}-5$ and $\mathrm{Mn} /$ beta catalysts via wet impregnation, and the catalytic performance compared at 50-350 ${ }^{\circ} \mathrm{C}$. Characterization methods including $\mathrm{N}_{2}$ adsorption/desorption, X-ray diffraction (XRD), X-ray fluorescence (XRF), $\mathrm{H}_{2}$ temperature-programmed reduction $\left(\mathrm{H}_{2}-\mathrm{TPR}\right), \mathrm{NH}_{3}$ temperature-programmed desorption ( $\mathrm{NH}_{3}$-TPD) and X-ray photoelectron spectroscopy (XPS) were used to identify the surface active $\mathrm{MnO}_{x}$ species over the catalysts and to investigate the influence of the manganese precursors on SCR performance.

\section{Experimental}

\subsection{Catalyst preparation}

Commercial H/beta and H/ZSM-5 (Si/Al = 25, Nankai University, China) served as the supports, and different Mn precursors such as manganese nitrate $\left(\mathrm{Mn}\left(\mathrm{NO}_{3}\right)_{2}, 50 \%\right.$ solution, Aladdin, China), manganese acetate $\left(\mathrm{Mn}\left(\mathrm{CH}_{3} \mathrm{COO}\right)_{2} \bullet 4 \mathrm{H}_{2} \mathrm{O}\right.$, Aladdin, China) and manganese chloride $\left(\mathrm{MnCl}_{2} \bullet 4 \mathrm{H}_{2} \mathrm{O}\right.$, Aladdin, China) were employed as the source of $\mathrm{Mn}$ to fabricate $\mathrm{Mn} /$ beta and Mn/ZSM-5 catalysts via wet impregnation. A desired quantity of manganese precursors and $50 \mathrm{~mL}$ distilled water formed the required solution to which $10 \mathrm{~g}$ of zeolite support (H/beta or H/ZSM-5) was added. The mixtures were constantly stirred at $30{ }^{\circ} \mathrm{C}$ for $5 \mathrm{~h}$, before heating in a water bath at $80^{\circ} \mathrm{C}$ to remove the excessive moisture. Thereafter, the samples were dried at $100{ }^{\circ} \mathrm{C}$ overnight and then calcined at $400{ }^{\circ} \mathrm{C}$ for $5 \mathrm{~h}$ in air. The obtained catalyst powders were ground to 100-200 mesh, pressed to form tablets using a tableting press, and crushed to 20-40 mesh. The catalysts were denoted as Mn/beta- $x$ or Mn/Z- $x$, where $x$ represents Ac (manganese acetate), $\mathrm{NO}_{3}$ (manganese nitrate) and $\mathrm{Cl}$ (manganese chloride). For example, Mn/beta-Ac or Mn/Z-Ac corresponds to $\mathrm{Mn} /$ beta or Mn/ZSM-5, respectively, prepared from the manganese acetate precursor. In this study, Mn loading was fixed at $20 \mathrm{wt} \%$ (based on the support) for all catalysts.

\subsection{Catalyst activity test}

For all prepared catalysts, SCR performance was evaluated using a fixed-bed quartz reactor (inner diameter $13 \mathrm{~mm}$ ) at a reaction temperature of $50-350{ }^{\circ} \mathrm{C}$ under atmospheric pressure. The reactor was equipped with a temperature-programming controller. Catalyst $\left(1.5 \mathrm{~cm}^{3}\right)$ was used for the catalytic assessment with a gas hourly space velocity (GHSV) of 50000 $\mathrm{h}^{-1}$, with the simulated flue gas (total flow rate of 1250 $\mathrm{mL} / \mathrm{min}$ ) comprising $0.1 \% \mathrm{NO}, 0.11 \% \mathrm{NH}_{3}, 5 \% \mathrm{O}_{2}$, and $\mathrm{N}_{2}$ as the balance gas. An online flue gas analyzer (Gasboard 3000) was employed to record the concentration of NO.

NO conversion was determined by the following equation:

$$
X_{\mathrm{ON}} \%=\frac{[\mathrm{NO}]_{\text {inlet }}-[\mathrm{NO}]_{\text {outlet }}}{[\mathrm{NO}]_{\text {inlet }}} \times 100
$$


where $[\mathrm{NO}]_{\text {inlet }}$ and $[\mathrm{NO}]_{\text {outlet }}$ correspond to the NO concentration at the inlet and outlet steady state, respectively.

\subsection{Catalyst characterization}

For all samples, the textural properties (specific surface area, total pore volume, average pore diameter) were measured at $-196{ }^{\circ} \mathrm{C}$ (liquid $\mathrm{N}_{2}$ temperature) using a Tristar 3020 (Micromeritics, Shanghai) nitrogen adsorption analyzer following a static-volumetric method. To remove adsorbed gases, the catalysts $(100 \mathrm{mg})$ were subjected to a degassing step by heating to $200{ }^{\circ} \mathrm{C}$ under vacuum for $4 \mathrm{~h}$ prior to any testing. Specific surface areas were measured via the Brunauer-Emmett-Teller (BET) model from the adsorption data.

XRD data were collected using an X-ray diffractometer (RU-200B, Rigaku, Japan) using $\mathrm{Cu} K_{\alpha}$ as the source of radiation at $40 \mathrm{kV}$ and $30 \mathrm{~mA}$. $2 \theta$ was scanned over a range of $10^{\circ}-70^{\circ}$ at a step size of $0.02^{\circ}$.

Residual chloride concentration in $\mathrm{Mn} / \mathrm{Z}-\mathrm{Cl}$ and $\mathrm{Mn} /$ beta-Cl was determined by XRF using a Panalytical Axios advanced instrument (Netherlands).

$\mathrm{H}_{2}$-TPR profiles were obtained using an AutoChem TPDR01100 chemisorption analyzer (Thermo Fisher, Italy). Catalysts $(50 \mathrm{mg})$ were pretreated by flowing $\mathrm{He}(50 \mathrm{~mL} / \mathrm{min})$ at $120{ }^{\circ} \mathrm{C}$ for $2 \mathrm{~h}$ before testing. After cooling to $30{ }^{\circ} \mathrm{C}$, a feed stream of $5 \% \mathrm{H}_{2}$ in He was fed to the catalyst at a flow rate of $50 \mathrm{~mL} / \mathrm{min}$, prior to increasing the temperature from $30^{\circ} \mathrm{C}$ to $700{ }^{\circ} \mathrm{C}$ (ramp rate of $10{ }^{\circ} \mathrm{C} / \mathrm{min}$ ). A thermal conductivity detector was applied to record $\mathrm{H}_{2}$ consumption.

$\mathrm{NH}_{3}$-TPD experiments were conducted using a Tianjin XQ TP-5080 multifunctional chemisorption analyzer. Catalysts (100 mg) were pretreated by flowing He $(50 \mathrm{~mL} / \mathrm{min})$ at 150 ${ }^{\circ} \mathrm{C}$ for $1 \mathrm{~h}$. Thereafter, the catalysts were saturated with $10 \%$ $\mathrm{NH}_{3}$ at $100{ }^{\circ} \mathrm{C}$ for $1 \mathrm{~h}$, followed by purging with pure He for $1 \mathrm{~h}$ to remove physically absorbed $\mathrm{NH}_{3}$. Finally, TPD profiles were obtained under a He atmosphere $(50 \mathrm{~mL} / \mathrm{min})$ from 100 to 500 ${ }^{\circ} \mathrm{C}$ (ramp rate of $10^{\circ} \mathrm{C} / \mathrm{min}$ ).

XPS profiles were collected using a surface analysis photoelectron spectrometer (ESCALAB 250Xi, USA), with $\mathrm{Al} K_{\alpha}$ as the source of radiation at $300 \mathrm{~W}$. For the purpose of eliminating sample charging effects, the binding energy (BE) values were corrected by the $\mathrm{C} 1 s$ line (284.6 eV), and an approximated error of $0.1 \mathrm{eV}$ was considered across all measurements. XPSPEAK 4.1 was used to deconvolute the Mn $2 p$ and $01 s$ spectra.

\section{Results and discussion}

\subsection{SCR activity}

Fig. 1 compares NO conversion performance of the Mn/beta and Mn/ZSM-5 catalysts across the temperature window of $50-350{ }^{\circ} \mathrm{C}$. It can be observed that both the precursor and support type influence SCR performance. At low temperatures, there are distinct differences in NO conversion. The $\mathrm{Mn} /$ beta-Cl and $\mathrm{Mn} / \mathrm{Z}-\mathrm{Cl}$ catalysts only converted approximately 50\% NO at $350{ }^{\circ} \mathrm{C}$, showing significantly less activity at low tempera-

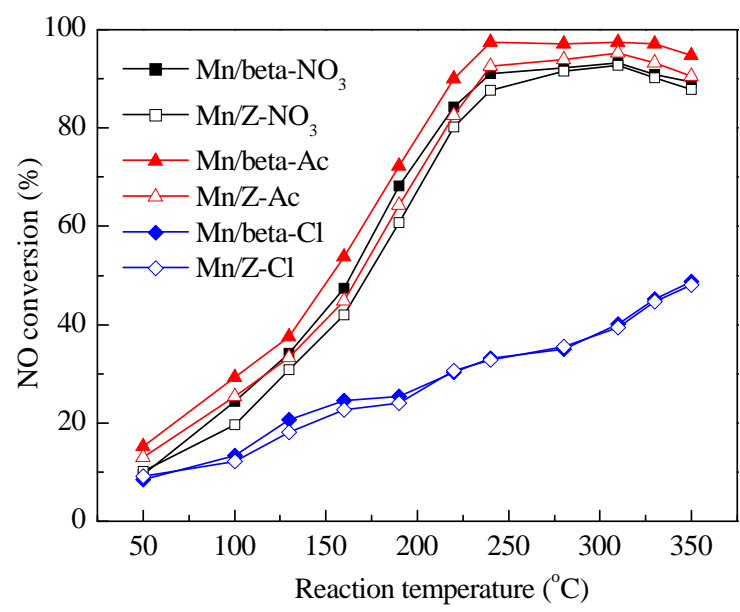

Fig. 1. Mn precursor influence on $\mathrm{NH}_{3}-\mathrm{SCR}$ activity of $\mathrm{Mn} /$ beta and Mn/ZSM-5 catalysts. Reaction conditions: $1.5 \mathrm{~cm}^{3}$ catalyst, $0.1 \%$ NO, $0.11 \% \mathrm{NH}_{3}, 5 \% \mathrm{O}_{2}, \mathrm{~N}_{2}$ balance, GHSV $=50000 \mathrm{~h}^{-1}$.

tures, possibly correlated to a lower degree of $\mathrm{MnCl}_{2}$ decomposition [30]. For the corresponding catalysts prepared using the manganese nitrate and manganese acetate precursors, all of which exhibited good catalytic activity, NO conversion remained high at $>80 \%$ from $220-350{ }^{\circ} \mathrm{C}$, albeit with a slight decline in activity at higher reaction temperatures owing to the non-selective oxidation of $\mathrm{NH}_{3}$ by oxygen $[16,26]$. From all the catalysts, Mn/beta-Ac exhibited the highest NO conversion $\left(97.5 \%\right.$ at $\left.240{ }^{\circ} \mathrm{C}\right)$, which remained over $90 \%$ across a temperature window of $220-350{ }^{\circ} \mathrm{C}$. For the $\mathrm{Mn} / \mathrm{Z}-\mathrm{Ac}, \mathrm{Mn} /$ beta- $\mathrm{NO}_{3}$ and $\mathrm{Mn} / \mathrm{Z}-\mathrm{NO}_{3}$ catalysts, NO conversion at $240{ }^{\circ} \mathrm{C}$ was $92.5 \%$, $91.1 \%$ and $87.6 \%$, respectively, and to maintain a NO conversion above $90 \%$, an operating temperature range of $240-350$ ${ }^{\circ} \mathrm{C}, 240-330{ }^{\circ} \mathrm{C}, 280-330{ }^{\circ} \mathrm{C}$ was needed, respectively. Hence, the activity test data shows $\mathrm{Mn} /$ beta-Ac and Mn/Z-Ac to perform considerably better than the corresponding $\mathrm{Mn} /$ beta- $\mathrm{NO}_{3}$ and $\mathrm{Mn} / \mathrm{Z}-\mathrm{NO}_{3}$ catalysts. Furthermore, $\mathrm{Mn} /$ beta-Ac displayed the maximum NO conversion across the largest active temperature range, indicating the excellent catalytic performance.

\section{2. $\mathrm{N}_{2}$ adsorption/desorption}

$\mathrm{N}_{2}$ adsorption/desorption isotherms for the parent $\mathrm{H} /$ beta and H/ZSM-5 zeolites, and the Mn/beta and Mn/ZSM-5 catalysts are shown in Fig. 2. The isotherms can be classified as type I, which is characteristic of microporous structures [20,31]. Table 1 summarizes the textural properties for all samples. Significant changes to the textural properties are observed after the introduction of Mn when compared with the parent H/beta and H/ZSM-5 supports, with both specific surface area and total pore volume decreasing. Conversely, for all catalysts, the average pore diameters increased after loading manganese, which is attributed to $\mathrm{MnO}_{x}$ species occluding the zeolite pores and channels, and larger $\mathrm{MnO}_{x}$ species being deposited over the catalyst surface resulting in the formation of new pores [32]. Specific surface areas of $\mathrm{Mn} /$ beta- $\mathrm{NO}_{3}, \mathrm{Mn} /$ beta-Ac and $\mathrm{Mn} /$ beta- $\mathrm{Cl}$ are 324, 363 and $296 \mathrm{~m}^{2} / \mathrm{g}$, respectively, while $\mathrm{Mn} / \mathrm{Z}-\mathrm{NO}_{3}, \mathrm{Mn} / \mathrm{Z}-\mathrm{Ac}, \mathrm{Mn} / \mathrm{Z}-\mathrm{Cl}$ present specific surface areas of 


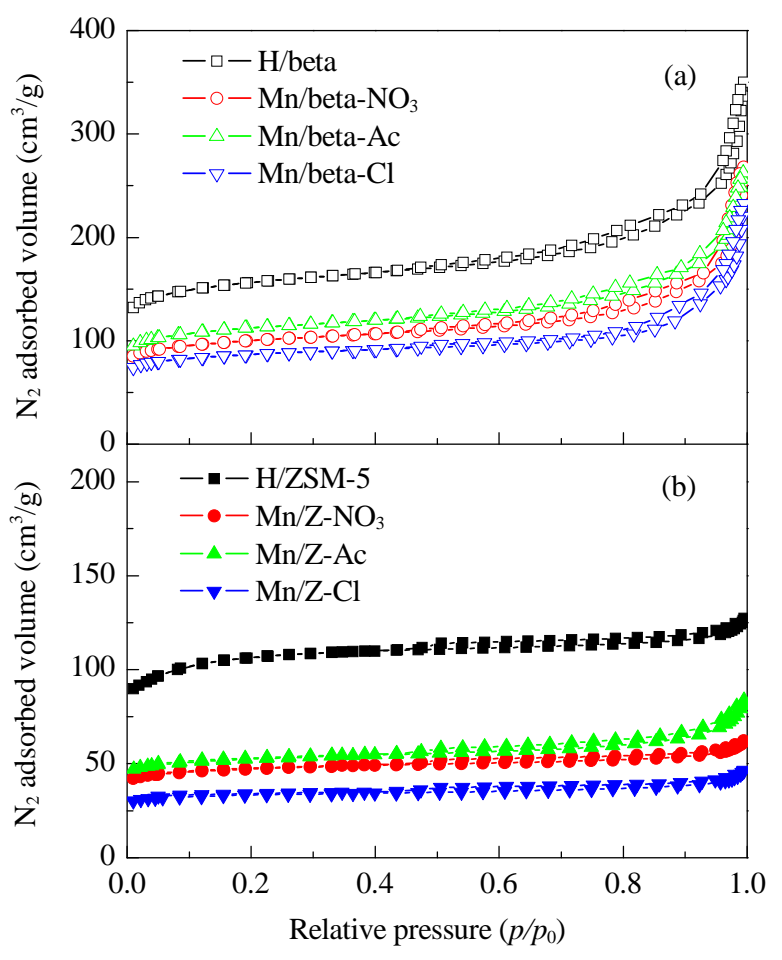

Fig. 2. $\mathrm{N}_{2}$ adsorption/desorption isotherms of (a) H/beta, Mn/beta catalysts and (b) H/ZSM-5, Mn/ZSM-5 catalysts.

Table 1

Catalyst textural properties.

\begin{tabular}{|c|c|c|c|}
\hline Sample & $A_{\mathrm{BET}} /\left(\mathrm{m}^{2} / \mathrm{g}\right)$ & $V_{\mathrm{P}} /\left(\mathrm{cm}^{3} / \mathrm{g}\right)$ & $d_{\mathrm{A}} / \mathrm{nm}$ \\
\hline H/beta & 507.79 & 0.49 & 3.87 \\
\hline $\mathrm{Mn} /$ beta- $\mathrm{NO}_{3}$ & 325.70 & 0.36 & 4.09 \\
\hline Mn/beta-Ac & 365.38 & 0.37 & 4.52 \\
\hline Mn/beta-Cl & 281.26 & 0.31 & 4.43 \\
\hline H/ZSM-5 & 343.89 & 0.19 & 2.24 \\
\hline $\mathrm{Mn} / \mathrm{Z}-\mathrm{NO}_{3}$ & 183.27 & 0.11 & 2.38 \\
\hline $\mathrm{Mn} / \mathrm{Z}-\mathrm{Ac}$ & 219.81 & 0.15 & 2.71 \\
\hline $\mathrm{Mn} / \mathrm{Z}-\mathrm{Cl}$ & 152.79 & 0.09 & 2.43 \\
\hline
\end{tabular}

219, 183 and $152 \mathrm{~m}^{2} / \mathrm{g}$, respectively. This indicates that when H/beta zeolite and H/ZSM-5 zeolite are employed as supports for Mn-based catalysts prepared with the same precursor, the
Mn/beta catalysts possessed higher specific surface areas. Additionally, for both Mn/beta catalysts and Mn/ZSM-5 catalysts, the catalysts prepared employing the manganese acetate precursor retained specific surface areas closer to the respective parent zeolite, which is likely to be attributed to $\mathrm{MnO}_{x}$ species being highly dispersed over the catalyst. The catalysts prepared using the manganese chloride precursors exhibited the greatest loss of specific surface area relative to the parent zeolite. It is interesting to observe that the changes to textural properties correlate to SCR performance. Hence, to a degree, the textural properties of the catalysts may influence catalytic activity. However, although some influence can be attributed to changes in textural properties, this is not a key factor, as the main factors to influence SCR activity are the zeolite structure and the catalyst active metal phase [18].

\section{3. $X R D$}

Fig. 3 presents the XRD patterns of Mn/beta and Mn/ZSM-5 catalysts together with the diffractograms of the parent supports (H/beta and H/ZSM-5). The Mn-loaded catalysts exhibit typical diffraction peaks of the respective parent zeolite indicating that structural integrity was retained. The diffractogram of $\mathrm{Mn} /$ beta- $\mathrm{NO}_{3}$ exhibited several strong characteristic peak reflections at $28.6^{\circ}, 37.3^{\circ}, 42.7^{\circ}, 56.6^{\circ}, 59.3^{\circ}, 64.9^{\circ}$ corresponding to pyrolusite $\left(\mathrm{MnO}_{2}\right.$, $\left.\mathrm{PDF} \# 24-735\right)$ [14,16]. Additionally, strong $\mathrm{MnO}_{2}$ diffraction peaks were also observed in the $\mathrm{Mn} / \mathrm{Z}-\mathrm{NO}_{3}$ catalyst. The results are consistent with Li et al. [33] who reported that the manganese nitrate precursor formed principally $\mathrm{MnO}_{2}$. For $\mathrm{Mn} /$ beta-Ac and $\mathrm{Mn} / \mathrm{Z}-\mathrm{Ac}$, the distinctive diffraction peaks observed at $32.4^{\circ}, 36.0^{\circ}$ and $59.9^{\circ}$ were assigned to crystalline $\mathrm{Mn}_{3} \mathrm{O}_{4}$ (PDF \#18-0803) [24]. However, the intensities of the $\mathrm{Mn}_{3} \mathrm{O}_{4}$ diffraction peaks were observed to be stronger for Mn/Z-Ac than for Mn/beta-Ac. This phenomenon may be explained by either the high dispersion of $\mathrm{Mn}_{3} \mathrm{O}_{4}$ in the $\mathrm{Mn} / \mathrm{Z}$-Ac catalyst or low $\mathrm{Mn}_{3} \mathrm{O}_{4}$ loading levels in the $\mathrm{Mn} /$ beta-Ac catalyst. Furthermore, although a small amount of crystalline $\mathrm{Mn}_{2} \mathrm{O}_{3}$ was previously reported on the surface of $\mathrm{MnO}_{x} / \mathrm{TiO}_{2}[9,14]$, no distinct peaks ascribed to $\mathrm{Mn}_{2} \mathrm{O}_{3}$ were detected in $\mathrm{Mn} /$ beta-Ac and $\mathrm{Mn} / \mathrm{Z}-\mathrm{Ac}$. Therefore, $\mathrm{Mn}_{2} \mathrm{O}_{3}$ can be
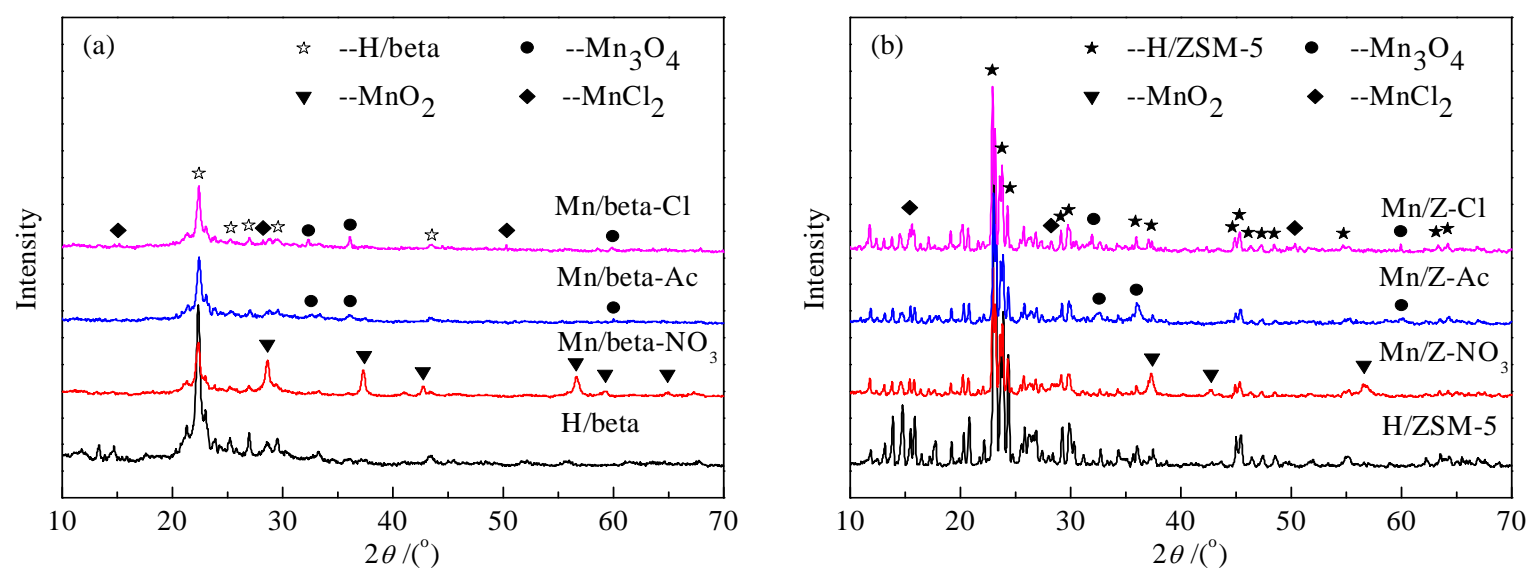

Fig. 3. XRD patterns for (a) H/beta and Mn/beta catalysts and (b) H/ZSM-5 and Mn/ZSM-5 catalysts. 
inferred to be either highly dispersed or in an amorphous state. However, with regard to the XRD patterns of $\mathrm{Mn} /$ beta- $\mathrm{Cl}$ and $\mathrm{Mn} / \mathrm{Z}-\mathrm{Cl}$, both $\mathrm{Mn}_{3} \mathrm{O}_{4}$ and $\mathrm{MnCl}_{2}$ species were detected, the latter assigned by the weak diffraction peaks at $15.1^{\circ}, 49.1^{\circ}$ and $50.3^{\circ}$ (PDF \#22-0720). Previous reports related to $\mathrm{MnCl}_{2}$ - modified zeolites show that $\mathrm{MnCl}_{2}$ is only partially decomposed when subjected to calcination temperatures of $310-600{ }^{\circ} \mathrm{C}$ $[34,35]$. Further increasing the calcination temperature above $600{ }^{\circ} \mathrm{C}$ results in the facile transformation to Mn oxides. Additionally, XRF results showed residual chloride content in $\mathrm{Mn} / \mathrm{Z}-\mathrm{Cl}$ and $\mathrm{Mn} /$ beta-Cl to be $13.41 \mathrm{wt} \%$ and $10.52 \mathrm{wt} . \%$ (based on the catalyst), respectively. The results indicate limited manganese chloride decomposition during the preparation of the catalysts prepared using the manganese chloride precursor, which compromises catalytic performance.

\section{4. $H_{2}-T P R$}

$\mathrm{H}_{2}$-TPR curves of the prepared catalysts are shown in Fig. 4. Table 2 lists reduction peak information (low-temperature peak denoted as peak-1 and high-temperature peak denoted peak-2) of all the catalysts, which shows that catalysts prepared with different precursors present distinct hydrogen consumption differences. For $\mathrm{Mn} /$ beta- $\mathrm{NO}_{3}$ and $\mathrm{Mn} / \mathrm{Z}-\mathrm{NO}_{3}$, the catalysts exhibit similar patterns, and both are characterized by two reduction peaks at $362,440{ }^{\circ} \mathrm{C}$ and $372,480{ }^{\circ} \mathrm{C}$, respectively. It is widely accepted that a sequential reduction process of bulk $\mathrm{MnO}_{x}$ proceeds and is often described as follows: $\mathrm{MnO}_{2} \rightarrow \mathrm{Mn}_{2} \mathrm{O}_{3} \rightarrow \mathrm{Mn}_{3} \mathrm{O}_{4} \rightarrow \mathrm{MnO}$ [36]. Furthermore, Qi et al. [9] introduced an equation (1) based on theoretical oxygen loss of $\mathrm{MnO}_{x}$ during each reduction step to determine the $\mathrm{MnO}_{x}$ species.

$$
6 \mathrm{MnO}_{2} \stackrel{-30}{\longrightarrow} 3 \mathrm{Mn}_{2} \mathrm{O}_{3} \stackrel{-0}{\rightarrow} 2 \mathrm{Mn}_{3} \mathrm{O}_{4} \stackrel{-20}{\longrightarrow} 6 \mathrm{MnO}
$$

The peak- 1 area to peak- 2 area ratios of $\mathrm{Mn} /$ beta- $\mathrm{NO}_{3}$ and $\mathrm{Mn} / \mathrm{Z}-\mathrm{NO}_{3}$ approach 2. Therefore, combining the $\mathrm{H}_{2}$ consumption data with the XRD results, the two reduction peaks of the catalysts correspond to a stepwise reduction of $\mathrm{MnO}_{2}$ to $\mathrm{Mn}_{2} \mathrm{O}_{3}$ $\mathrm{Mn}_{3} \mathrm{O}_{4}$ and finally to $\mathrm{MnO}$, which is complementary to the results reported by Fang et al. [14]. The two reduction peaks of
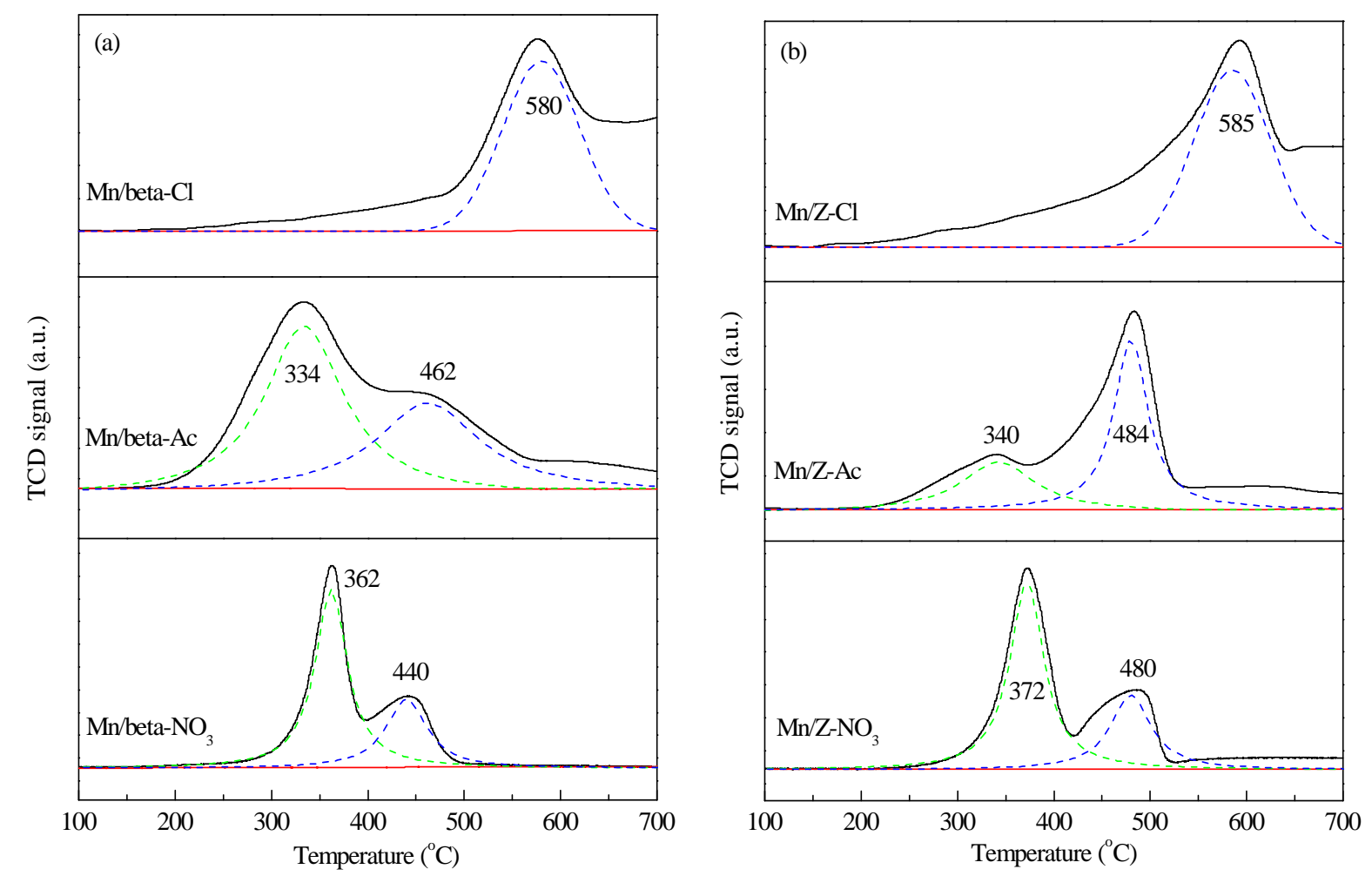

Fig. 4. $\mathrm{H}_{2}$-TPR profiles of (a) Mn/beta catalysts and (b) Mn/ZSM-5 catalysts.

Table 2

Catalyst hydrogen consumption as a function of temperature.

\begin{tabular}{|c|c|c|c|c|c|c|}
\hline \multirow{2}{*}{ Sample } & \multicolumn{2}{|c|}{ Peak temperature $\left({ }^{\circ} \mathrm{C}\right)$} & \multicolumn{2}{|c|}{ Peak area (a.u.) } & \multirow{2}{*}{$\begin{array}{c}\text { Ratio } \\
\text { Peak-1/Peak-2 }\end{array}$} & \multirow{2}{*}{$\begin{array}{l}\text { Total } \\
\text { area }\end{array}$} \\
\hline & Peak-1 & Peak-2 & Peak-1 & Peak-2 & & \\
\hline $\mathrm{Mn} /$ beta- $\mathrm{NO}_{3}$ & 362 & 440 & 82000 & 43000 & 1.9 & 125000 \\
\hline Mn/beta-Ac & 334 & 462 & 27000 & 21000 & 1.3 & 48000 \\
\hline $\mathrm{Mn} /$ beta-Cl & - & 580 & - & 11000 & - & 11000 \\
\hline $\mathrm{Mn} / \mathrm{Z}-\mathrm{NO}_{3}$ & 372 & 480 & 75000 & 39000 & 1.9 & 114000 \\
\hline $\mathrm{Mn} / \mathrm{Z}-\mathrm{Ac}$ & 340 & 484 & 19000 & 27000 & 0.7 & 46000 \\
\hline $\mathrm{Mn} / \mathrm{Z}-\mathrm{Cl}$ & - & 585 & - & 8000 & - & 8000 \\
\hline
\end{tabular}


$\mathrm{Mn} /$ beta-Ac and Mn/Z-Ac are located at $334,462{ }^{\circ} \mathrm{C}$ and 340 , $484{ }^{\circ} \mathrm{C}$, respectively. For $\mathrm{Mn} /$ beta-Ac, the peak- 1 area to peak- 2 area ratio is 1.3 , however, this ratio lowers to 0.7 for $\mathrm{Mn} / \mathrm{Z}$-Ac. Based on the equation (1), it can be concluded that $\mathrm{MnO}_{2}$ content is higher than that of $\mathrm{Mn}_{2} \mathrm{O}_{3}$ in $\mathrm{Mn} /$ beta-Ac, while $\mathrm{Mn} / \mathrm{Z}-\mathrm{Ac}$ showed the opposite result. Hence, the catalyst low-temperature peaks are attributed to the reduction of $\mathrm{MnO}_{2}$ and $\mathrm{Mn}_{2} \mathrm{O}_{3}$ to $\mathrm{Mn}_{3} \mathrm{O}_{4}$, while the high-temperature peaks correlate to the reduction of $\mathrm{Mn}_{3} \mathrm{O}_{4}$ to $\mathrm{MnO}$. Additionally, analysis of the XRD data showed only the presence of $\mathrm{Mn}_{3} \mathrm{O}_{4}$ in the catalysts. Hence, we propose that $\mathrm{Mn}_{2} \mathrm{O}_{3}$ and $\mathrm{MnO}_{2}$ were highly dispersed in the catalysts, similar to that previously reported $[9,13]$. Furthermore, $\mathrm{H}_{2}$ consumption (peak-1) for $\mathrm{Mn} /$ beta-Ac was greater than that of Mn/Z-Ac, suggesting a higher abundance of active oxygen species in Mn/beta-Ac, which enhanced SCR performance at low temperatures [37]. Conversely, when compared with $\mathrm{Mn} / \mathrm{Z}-\mathrm{NO}_{3}$ and $\mathrm{Mn} / \mathrm{Z}-\mathrm{Ac}, \mathrm{Mn} /$ beta- $\mathrm{NO}_{3}$ and $\mathrm{Mn} /$ beta-Ac displayed lower peak-1 temperatures, respectively, indicating the higher reducibility of the $\mathrm{MnO}_{x}$ species, which favored the low-temperature catalytic performance [19].

However, for $\mathrm{Mn} /$ beta-Cl and $\mathrm{Mn} / \mathrm{Z}-\mathrm{Cl}$, only high-temperature peaks were displayed in the $\mathrm{H}_{2}$-TPR profiles, with reduction temperatures of $\sim 580$ and $\sim 585{ }^{\circ} \mathrm{C}$, respectively. The broad redox peak for each catalyst was assigned to the reduction of $\mathrm{Mn}_{3} \mathrm{O}_{4}$ to $\mathrm{MnO}$ [38], which is in agreement with previous XRD results that presented the $\mathrm{Mn}_{3} \mathrm{O}_{4}$ phase. Additionally, $\mathrm{H}_{2}$ consumption of the catalysts prepared in the presence of the manganese chloride precursor was appreciably lower than the other catalysts, suggesting very low content of the active $\mathrm{MnO}_{x}$ species in the catalysts. Combining the XRD and XRF results, this phenomena can be explained by the low level of $\mathrm{MnCl}_{2}$ decomposition under the preparation conditions employed, which also complements the lowest $A_{\text {вет }}$ (Table 1) observed among the Mn/beta and Mn/ZSM-5 catalysts. Accordingly, these results demonstrated that the catalysts prepared using the manganese chloride precursor were inactive for the $\mathrm{NH}_{3}$-SCR process.

\section{5. $\mathrm{NH}_{3}-\mathrm{TPD}$}

There is scientific agreement on the importance of acid sites to the $\mathrm{NH}_{3}$-SCR reaction because $\mathrm{NH}_{3}$ adsorbs onto the acid sites and activates the reductant [27]. Additionally, according to a previous report, weak acid sites favor low-temperature catalytic performance, while strong acid sites influence the $\mathrm{NH}_{3}$-SCR reaction at high temperatures [19]. Therefore, for the purpose of further analyzing the surface properties of the $\mathrm{Mn} /$ beta and Mn/ZSM-5 catalysts, the surface acidity properties of these samples were quantitatively investigated by $\mathrm{NH}_{3}$-TPD. Catalyst $\mathrm{NH}_{3}$-TPD profiles are presented in Fig. 5. As can be observed from the $\mathrm{NH}_{3}$-TPD data, the catalysts prepared using the manganese acetate and manganese nitrate precursors present two desorption peaks, whereas, the catalysts prepared employing the manganese chloride precursor displayed only low-temperature desorption peaks. Previous studies have identified the desorption peaks of weak acid sites being presented at low temperatures $\left(150-250{ }^{\circ} \mathrm{C}\right)$, and have attributed

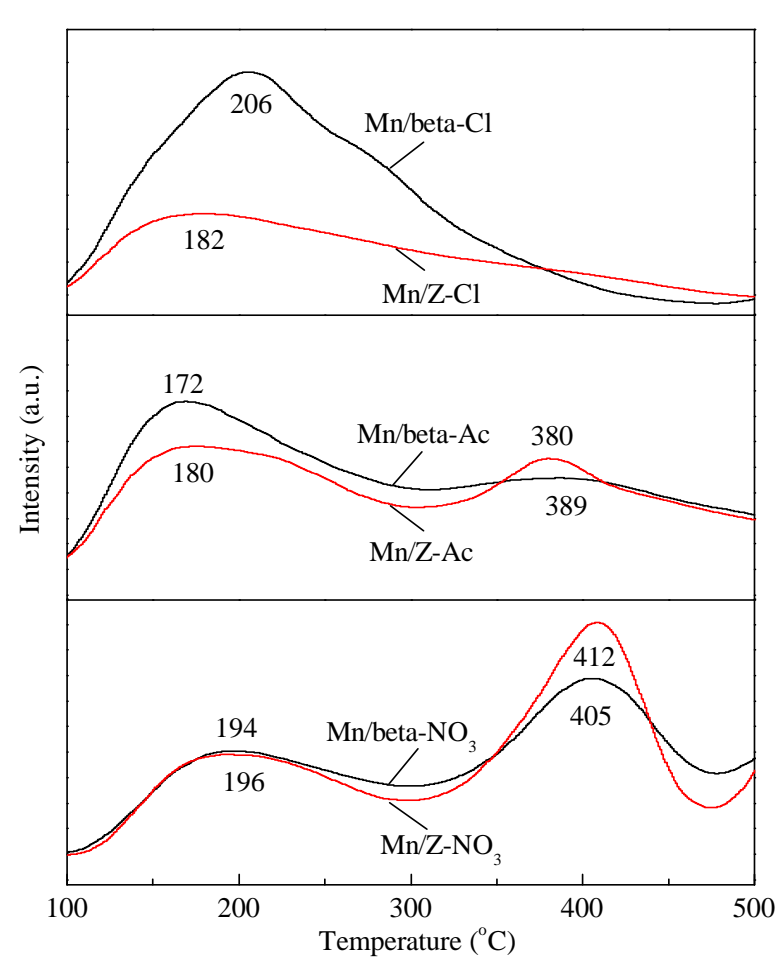

Fig. 5. $\mathrm{NH}_{3}$-TPD profiles of (a) Mn/beta catalysts and (b) Mn/ZSM-5 catalysts.

the desorption peaks centered at high temperatures (350-500 $\left.{ }^{\circ} \mathrm{C}\right)$ to strong acid sites $[10,24]$. Weak acid concentrations of the catalysts were obtained by integrating the desorption peak area with the results for $\mathrm{Mn} /$ beta-Cl, $\mathrm{Mn} / \mathrm{Z}-\mathrm{Cl}, \mathrm{Mn} /$ beta-Ac, $\mathrm{Mn} / \mathrm{Z}-\mathrm{Ac}, \mathrm{Mn} /$ beta- $\mathrm{NO}_{3}$ and $\mathrm{Mn} / \mathrm{Z}-\mathrm{NO}_{3}$ as 4000, 1800, 1650, 1350, 1050 and 950, respectively. $\mathrm{Mn} /$ beta-Cl and $\mathrm{Mn} / \mathrm{Z}-\mathrm{Cl}$ are observed to retain the highest quantity of weakly acidic centers compared with the other catalysts. However, these catalysts exhibited poor SCR performance because of the extremely low presence of active $\mathrm{MnO}_{x}$ species. Hence, it is inferred that the concentration of weak acid sites is not the determinant factor for SCR performance $[19,27]$. Conversely, with respect to the catalysts prepared employing the manganese acetate and manganese nitrate precursors, all of which displayed an abundance of the active phase, catalytic performance was enhanced. $\mathrm{Mn} /$ beta- $\mathrm{NO}_{3}$ and $\mathrm{Mn} /$ beta-Ac possessed higher concentrations of weak acid sites than the corresponding $\mathrm{Mn} / \mathrm{Z}-\mathrm{NO}_{3}$ and $\mathrm{Mn} / \mathrm{Z}$-Ac catalysts. Additionally, from either the $\mathrm{Mn} / \mathrm{beta}$ or Mn/ZSM-5 catalysts, employing the manganese acetate precursor resulted in the presence of significantly more weak acid sites than the corresponding catalysts prepared using the manganese nitrite precursor. These observations are in good agreement with the SCR activity results. Therefore, for lowtemperature SCR performance, it is proposed that an appropriate amount of weakly acidic centers may be advantageous.

\section{6. $X P S$}

XPS analysis was performed to further explore the chemical species and surface atomic composition of the catalysts pre- 

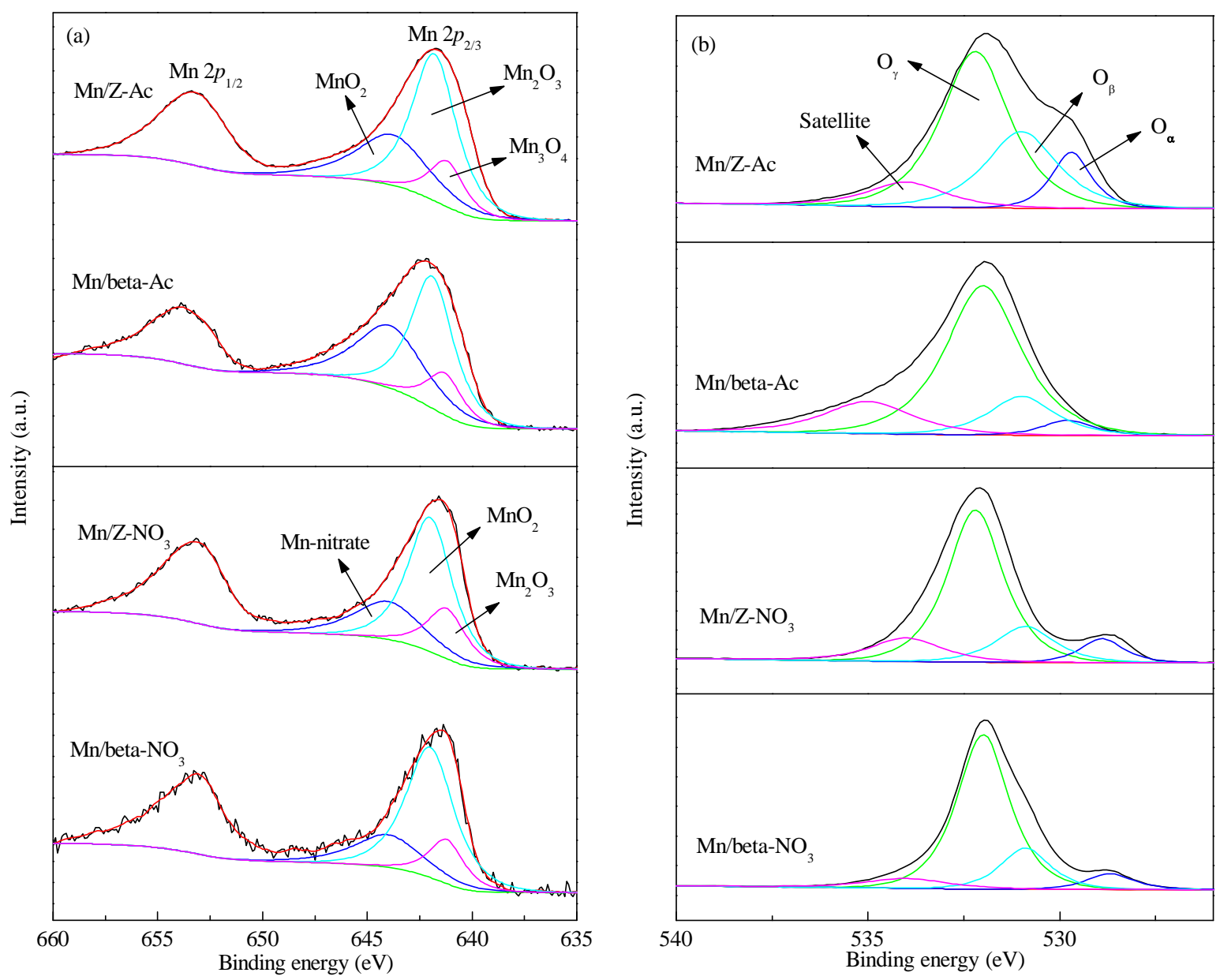

Fig. 6. XPS spectra of $\mathrm{Mn} /$ beta- $\mathrm{NO}_{3}, \mathrm{Mn} /$ beta-Ac, $\mathrm{Mn} / \mathrm{Z}-\mathrm{NO}_{3}$ and $\mathrm{Mn} / \mathrm{Z}-\mathrm{Ac}$. (a) $\mathrm{Mn} 2 p$; (b) $01 s$.

pared using the manganese nitrate and manganese acetate precursors. Fig. 6 displays the Mn $2 p$ and $01 s$ spectra of the catalysts. Surface atomic concentrations of Mn, detected by XPS, are listed in Table 3. Mn/beta-Ac showed the maximum surface manganese concentration, suggesting a high dispersion of manganese in this catalyst, which enhanced catalytic performance [16]. For all samples, the Mn $2 p$ spectra (Fig. 6(a)) displays two broad peaks located at $\sim 642 \mathrm{eV}$ and $653 \mathrm{eV}$ ascribed to Mn $2 p_{3 / 2}$ and Mn $2 p_{1 / 2}$, respectively [39]. For catalysts prepared using the manganese nitrate precursor, the Mn $2 p_{3 / 2}$ spectra was deconvoluted and fitted with three components: $\mathrm{Mn}_{2} \mathrm{O}_{3}(641.2 \mathrm{eV}), \mathrm{MnO}_{2}(642 \mathrm{eV})[13,15]$ and an obvious peak at $644.2 \pm 0.4 \mathrm{eV}$ corresponding to Mn-nitrate [40,41]. This result proved that manganese nitrate decomposed incompletely when subjected to a low sintering temperature of 400 ${ }^{\circ} \mathrm{C}$. With regard to the catalysts employing the manganese acetate precursor, Mn 2 $p_{3 / 2}$ can be deconvoluted into three peaks located at $641.3,641.8$ and $643.8 \mathrm{eV}$ correlating to $\mathrm{Mn}_{3} \mathrm{O}_{4}$, $\mathrm{Mn}_{2} \mathrm{O}_{3}$ and $\mathrm{MnO}_{2}$, respectively $[16,42,43]$, suggesting the coexistence of $\mathrm{Mn}_{3} \mathrm{O}_{4}, \mathrm{Mn}_{2} \mathrm{O}_{3}$ and $\mathrm{MnO}_{2}$ at the surface of $\mathrm{Mn} /$ beta-Ac and $\mathrm{Mn} / \mathrm{Z}$-Ac. XPS data reveals that surface $\mathrm{MnO}_{2}$ is the main $\mathrm{MnO}_{x}$ species present in $\mathrm{Mn} /$ beta- $\mathrm{NO}_{3}$ and $\mathrm{Mn} / \mathrm{Z}-\mathrm{NO}_{3}$, while a large percentage of $\mathrm{MnO}_{2}$ and $\mathrm{Mn}_{2} \mathrm{O}_{3}$ were observed in
$\mathrm{Mn} /$ beta-Ac and Mn/Z-Ac. These results are also in agreement with the $\mathrm{H}_{2}$-TPR studies. Previous reports have observed that the coexistence of $\mathrm{MnO}_{2}-\mathrm{Mn}_{2} \mathrm{O}_{3}$ could not only promote the oxidation of $\mathrm{NH}_{3}$, but also the oxidation of $\mathrm{NO}$ to $\mathrm{NO}_{2}$, which improved the SCR performance at low temperature $[1,4,44]$. Additionally, in this study, considering that the catalysts prepared using the manganese acetate precursor showed superior catalytic performance, it is proposed that the presence of $\mathrm{MnO}_{2}$ and $\mathrm{Mn}_{2} \mathrm{O}_{3}$ may play a key role in the SCR process. As expected, $\mathrm{Mn} /$ beta-Ac can be observed (Table 3) to possess a greater presence of active $\mathrm{MnO}_{x}\left(\mathrm{MnO}_{2}\right.$ and $\left.\mathrm{Mn}_{2} \mathrm{O}_{3}\right)$ species than the other catalysts, resulting in excellent catalytic performance. The $\mathrm{Mn} 2 p_{3 / 2}$ BEs of $\mathrm{Mn}_{2} \mathrm{O}_{3}$ and $\mathrm{MnO}_{2}$ for the catalysts prepared employing the manganese acetate precursor are nearly 0.6-1.8 $\mathrm{eV}$ higher than the corresponding catalysts prepared using the manganese nitrate precursor, showing that the manganese acetate precursor may have induced the high dispersion of the $\mathrm{MnO}_{x}$ species, which resulted in a stronger electrostatic field [1]. Again, the results are in agreement with the observations from XRD and $\mathrm{H}_{2}$-TPR data.

Fig. 6 presents the deconvoluted 0 1s spectra of the catalysts. Three distinct peaks are observed, located at 528.7530.0, 530.9-531.0 and 532.0-532.2 eV, and are attributed to 
Table 3

Surface atomic concentration, binding energies (BE) and the percent of different manganese species determined from deconvoluted XPS spectra.

\begin{tabular}{|c|c|c|c|c|c|c|c|c|}
\hline \multirow{2}{*}{ Sample } & \multicolumn{3}{|c|}{ Surface concentration (at \%) } & \multicolumn{5}{|c|}{ Percent of manganese species (\%) (BE, eV) } \\
\hline & $\mathrm{Mn}$ & 0 & Others ${ }^{a}$ & $\mathrm{Mn}_{3} \mathrm{O}_{4}$ & $\mathrm{Mn}_{2} \mathrm{O}_{3}$ & $\mathrm{MnO}_{2}$ & Mn-nitrate & $\mathrm{Mn}_{2} \mathrm{O}_{3}+\mathrm{MnO}_{2}$ \\
\hline $\mathrm{Mn} /$ beta- $\mathrm{NO}_{3}$ & 4.27 & 61.91 & 33.82 & - & $13.3(641.2)$ & $66.7(642.0)$ & $20.0(643.8)$ & 80.0 \\
\hline Mn/beta-Ac & 8.73 & 62.34 & 28.93 & $14.2(641.3)$ & $40.2(641.8)$ & $45.6(643.8)$ & - & 85.8 \\
\hline $\mathrm{Mn} / \mathrm{Z}-\mathrm{NO}_{3}$ & 3.12 & 59.43 & 37.45 & - & $15.9(641.2)$ & $61.9(642.0)$ & $22.2(644.0)$ & 77.8 \\
\hline $\mathrm{Mn} / \mathrm{Z}-\mathrm{Ac}$ & 5.54 & 61.52 & 32.94 & $17.1(641.3)$ & $55.6(641.8)$ & $27.3(643.8)$ & - & 82.9 \\
\hline
\end{tabular}

a Other elements include $\mathrm{Si}, \mathrm{Al}, \mathrm{C}$.

Table 4

$\mathrm{BE}$ and $\mathrm{O}_{\beta} /\left(\mathrm{O}_{\beta}+\mathrm{O}_{\alpha}\right)$ ratios.

\begin{tabular}{|c|c|c|c|c|}
\hline \multirow{2}{*}{ Sample } & \multicolumn{3}{|c|}{$\mathrm{BE}(\mathrm{eV})$} & \multirow{2}{*}{$\mathrm{O}_{\beta} /\left(\mathrm{O}_{\beta}+\mathrm{O}_{\alpha}\right)^{\mathrm{a}}$} \\
\hline & $\mathrm{O}_{\alpha}$ & $\mathrm{O}_{\beta}$ & $\mathrm{O}_{\gamma}$ & \\
\hline $\mathrm{Mn} /$ beta- $\mathrm{NO}_{3}$ & 528.7 & 531.0 & 532.0 & 0.74 \\
\hline Mn/beta-Ac & 530.0 & 531.0 & 532.0 & 0.77 \\
\hline $\mathrm{Mn} / \mathrm{Z}-\mathrm{NO}_{3}$ & 528.9 & 530.9 & 532.2 & 0.68 \\
\hline $\mathrm{Mn} / \mathrm{Z}-\mathrm{Ac}$ & 529.7 & 531.0 & 532.2 & 0.71 \\
\hline
\end{tabular}

${ }^{\mathrm{a}} \mathrm{O}_{\beta} /\left(\mathrm{O}_{\beta}+\mathrm{O}_{\alpha}\right)=A_{\mathrm{o} \beta} /\left(A_{\mathrm{o} \beta}+A_{\mathrm{o} \alpha}\right)$.

lattice oxygen $\mathrm{O}^{2-}$ (labeled as $\mathrm{O}_{\alpha}$ ), surface labile oxygen such as $\mathrm{O}^{-}$or $\mathrm{OH}^{-}$belonging to defect-oxide or hydroxyl-like groups (designated as $\mathrm{O}_{\beta}$ ), and other absorbed oxygen species (labeled as $O_{\gamma}$ ), respectively $[27,37,45]$. Furthermore, to reduce error, the peak at $533-534 \mathrm{eV}$ was assigned as a satellite peak. Table 4 lists the quantitative data of $\mathrm{O}_{\beta} /\left(\mathrm{O}_{\beta}+\mathrm{O}_{\alpha}\right)$ ratios of the catalysts calculated by the relative peaks areas. Previous studies have noted the importance of surface chemisorbed labile oxygen $\left(\mathrm{O}_{\beta}\right)$ in the SCR process at low temperatures, which is considered to be the most active oxygen because of its high mobility and that it plays a vital role in the oxidation reaction [37]. Accordingly, the high ratio of $\mathrm{O}_{\beta} /\left(\mathrm{O}_{\beta}+\mathrm{O}_{\alpha}\right)$ was conducive to NO oxidation to $\mathrm{NO}_{2}$, which enhanced the low-temperature catalytic performance by a "Fast-SCR" route $[46,47]$. In our present study, the $\mathrm{O}_{\beta} /\left(\mathrm{O}_{\beta}+\mathrm{O}_{\alpha}\right)$ ratios of $\mathrm{Mn} /$ beta-Ac and $\mathrm{Mn} /$ beta- $\mathrm{NO}_{3}$ were significantly higher than those of $\mathrm{Mn} / \mathrm{Z}-\mathrm{Ac}$ and $\mathrm{Mn} / \mathrm{Z}-\mathrm{NO}_{3}$, respectively. Conversely, from the $\mathrm{Mn} /$ beta catalysts, $\mathrm{Mn} /$ beta-Ac possessed more surface labile oxygen than $\mathrm{Mn} /$ beta- $\mathrm{NO}_{3}$, and similar results were observed for the Mn/ZSM- 5 catalysts. The results are also in good agreement with the SCR performance.

\section{Conclusion}

We compared the $\mathrm{NH}_{3}$-SCR performance and physicochemical properties between $\mathrm{Mn} /$ beta and Mn/ZSM-5 catalysts, which were prepared using manganese nitrate, manganese acetate and manganese chloride precursors. From the Mn/beta and $\mathrm{Mn} / \mathrm{ZSM}-5$ catalysts, $\mathrm{Mn} /$ beta-Cl and $\mathrm{Mn} / \mathrm{Z}-\mathrm{Cl}$ displayed extremely low NO conversion $\left(\sim 50 \%\right.$ at $\left.350{ }^{\circ} \mathrm{C}\right)$, while $\mathrm{Mn} /$ beta-Ac showed excellent catalytic performance, displaying the highest NO conversion of $97.5 \%$ at $240{ }^{\circ} \mathrm{C}$ while maintaining $>90 \%$ conversion across the widest active temperature range of $220-350{ }^{\circ} \mathrm{C}$. BET results revealed that the textural properties may influence SCR performance, to a degree. XRD, XRF and $\mathrm{H}_{2}$-TPR results show that the catalysts prepared employing the manganese chloride precursor present poor catalytic activity because of low $\mathrm{MnCl}_{2}$ decomposition yielding only a small quantity of crystalline $\mathrm{Mn}_{3} \mathrm{O}_{4}$. XPS analyses revealed that samples prepared using the manganese nitrate precursor resulted in crystalline $\mathrm{MnO}_{2}$ with a small presence of $\mathrm{Mn}$ nitrate, and employing the manganese acetate precursor resulted primarily in a mixture of highly dispersed $\mathrm{Mn}_{2} \mathrm{O}_{3}$ and $\mathrm{MnO}_{2}$, and crystalline $\mathrm{Mn}_{3} \mathrm{O}_{4}$. Additionally, combining the SCR activity data with the physicochemical properties suggests that the enhancement of catalytic performance can be attributed to the coexistence of amorphous $\mathrm{MnO}_{x}\left(\mathrm{Mn}_{2} \mathrm{O}_{3}\right.$ and $\left.\mathrm{MnO}_{2}\right)$ species. Conversely, systematical analysis revealed that the superior catalytic activity of $\mathrm{Mn} /$ beta-Ac correlates to the increased amorphous $\mathrm{Mn}_{2} \mathrm{O}_{3}$ and $\mathrm{MnO}_{2}$ content, higher concentration of surface manganese and surface labile oxygen. Furthermore, $\mathrm{NH}_{3}$-TPD results indicated that manganese-modified beta zeolite possessed an appropriate number of weakly acidic centers, which may favor the catalytic performance at low temperatures. Therefore, $\mathrm{Mn} /$ beta-Ac can be considered as a promising material for the preparation of manganese-supported SCR denitration catalysts in future applications.

\section{References}

[1] E. Park, S. Chin, J. Jeong, J. Jurng, Microporous Mesoporous Mater., 2012, 163, 96-101.

[2] S. Cimino, L. Lisi, M. Tortorelli, Chem. Eng. J., 2016, 283, 223-230.

[3] M. Stanciulescu, G. Caravaggio, A. Dobri, J. Moir, R. Burich, J. P. Charland, P. Bulsink, Appl. Catal. B, 2012, 123-124, 229-240.

[4] J. Li, C. W. Yang, Q. Zhang, Z. Li, W. Huang, Catal. Commun., 2015, 62, 24-28.

[5] X. Y. Fan, F. M. Qiu, H. S. Yang, W. Tian, T. F. Hou, X. B. Zhang, Catal. Commun., 2011, 12, 1298-1301.

[6] B. Q. Xu, H. D. Xu, T. Lin, Y. Cao, L. Lan, Y. S. Li, X. Feng, M. C. Gong, Y. Q. Chen, Chin. J. Catal., 2016, 37, 1354-1361.

[7] Y. K. Yu, J. S. Chen, J. X. Wang, Y. T. Chen, Chin. J. Catal., 2016, 37, 281-287.

[8] G. Lü, F. Bin, C. L. Song, K. P. Wang, J. O. Song, Fuel, 2013, 107, 217-224.

[9] K. Qi, J. L. Xie, D. Fang, F. X. Li, F. He, Chin. J. Catal., 2017, 38, $845-852$.

[10] J. L. Zuo, Z. H. Chen, F. R. Wang, Y. H. Yu, L. F. Wang, X. H. Li, Ind. Eng. Chem. Res., 2014, 53, 2647-2655.

[11] A. M. E. Raj, S. G. Victoria, V. B. Jothy, C. Ravidhas, J. Wollschläger, M. Suendorf, M. Neumann, M. Jayachandran, C. Sanjeeviraja, Appl. Surf. Sci., 2010, 256, 2920-2926.

[12] T. Wang, C. Z. Zhu, H. B. Liu, Y. P. Xu, X. H. Zou, B. Xu, T. H. Chen, Environ. Technol., 2017, 1-10.

[13] S. Hwang, S. H. Jo, J. Kim, M. C. Shin, H. H. Chun, H. Park, H. Lee, Reac. Kinet. Mech. Catal., 2016, 117, 583-591.

[14] D. Fang, J. L. Xie, H. Hu, H. Yang, F. He, Z. B. Fu, Chem. Eng. J., 2015, 271, 23-30. 


\section{Graphical Abstract}

Chin. J. Catal., 2018, 39: 118-127 doi: 10.1016/S1872-2067(17)62983-8

\section{Mn/beta and Mn/ZSM-5 for the low-temperature selective catalytic reduction of NO with ammonia: Effect of manganese precursors}

Wenjin Xu, Guangxu Zhang*, Hanwei Chen, Guomeng Zhang, Yang Han, Yichuan Chang, Peng Gong Wuhan University of Technology; Shanghai Hengyuan Marine Equipment Co., Ltd.

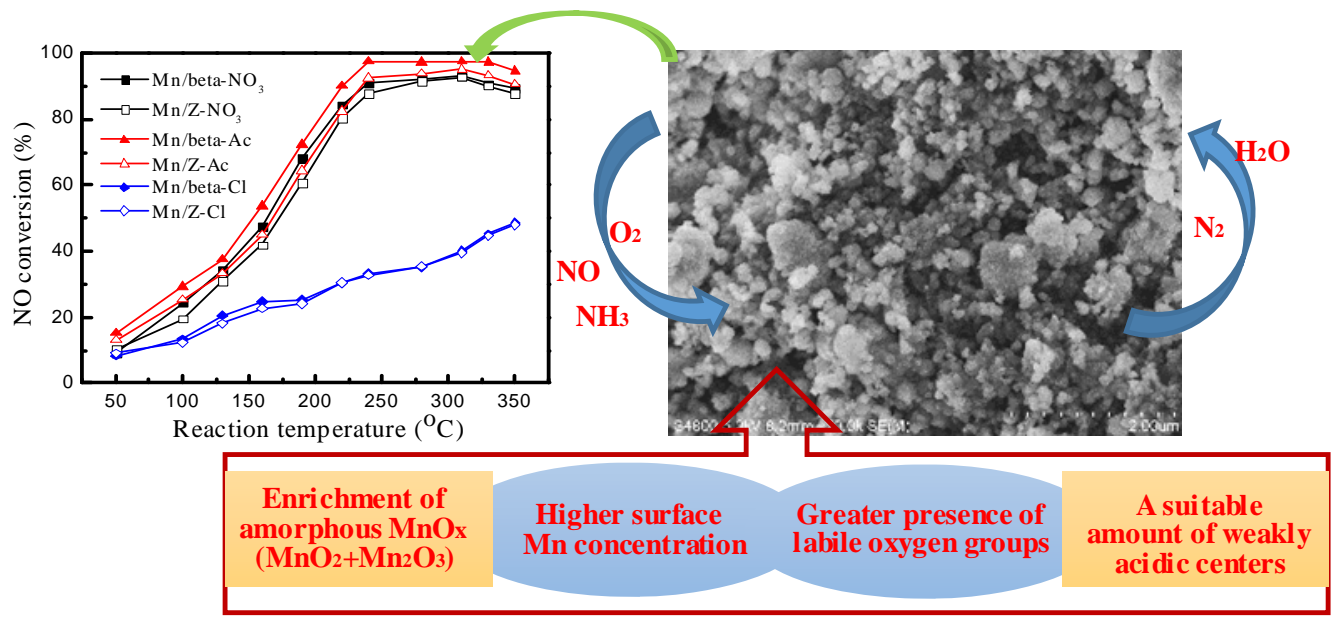

$\mathrm{Mn}$ /beta-Ac showed excellent low-temperature $\mathrm{NH}_{3}$-SCR performance attributed to a combination of enriching the amorphous $\mathrm{MnO}_{x}$ $\left(\mathrm{MnO}_{2}\right.$ and $\left.\mathrm{Mn}_{2} \mathrm{O}_{3}\right)$ content, higher surface manganese concentration and labile oxygen groups, and a suitable number of weakly acidic centers.

[15] D. A. Peña, B. S. Uphade, P. G. Smirniotis, J. Catal., 2004, 221, 421-431.

[16] X. R. Lou, P. F. Liu, J. Li, Z. Li, K. He, Appl. Surf. Sci., 2014, 307, 382-387.

[17] X. J. Yao, K. L. Ma, W. X. Zou, S. G. He, J. B. An, F. M. Yang, L. Dong, Chin. J. Catal., 2017, 38, 146-159.

[18] L. Li, L. S. Wang, S. W. Pan, Z. L. Wei, B. C. Huang, Chin. J. Catal,, 2013, 34, 1087-1097.

[19] A. Sultana, M. Sasaki, H. Hamada, Catal. Today, 2012, 185, 284-289.

[20] Y. Xia, W. C. Zhan, Y. Guo, Y. L. Guo, G. Z. Lu, Chin. J. Catal., 2016, 37, 2069-2078.

[21] S. W. Chen, X. L. Yan, J. Q. Chen, J. H. Ma, R. F. Li, Chin. J. Catal, 2010, 31, 1107-1114.

[22] D. S. Krivoruchenko, A. V. Kucherov, N. S. Telegina, D. A. Bokarev, P. Selvam, A. Y. Stakheev, Russ. Chem. Bull., 2014, 63, 389-395.

[23] Q. C. Lin, J. H. Li, L. Ma, J. M. Hao, Catal. Today, 2010, 151, 251-256.

[24] C. L. Yu, L. F. Dong, F. Chen, X. Q. Liu, B. C. Huang, Environ. Technol., 2017, 38, 1030-1042.

[25] G. Carja, Y. Kameshima, K. Okada, C. D. Madhusoodana, Appl. Catal. $B, 2007,73,60-64$.

[26] W. T. Mu, J. Zhu, S. Zhang, Y. Y. Guo, L. Q. Su, X. Y. Li, Z. Li, Catal. Sci. Technol., 2016, 6, 7532-7548.

[27] A. M. Frey, S. Mert, J. Due-Hansen, R. Fehrmann, C. H. Christensen, Catal. Lett., 2009, 130, 1-8.

[28] A. Corma, V. Fornes, E. Palomares, Appl. Catal. B, 1997, 11, 233-242.

[29] R. R. Gao, X. R. Lou, W. J. Bai, W. T. Mu, Z. Li, J. Mol. Catal. (China), 2015, 29, 563-574.
[30] S. Vankova, T. Tsoncheva, D. Mehandjiev, Catal. Commun., 2004, 5, 95-99.

[31] M. Thommes, Chem. Ing. Tech., 2010, 82, 1059-1073.

[32] Y. X. Yang, J. W. Ma, C. L. Yu, M. T. Sun, B. C. Huang, Y. M. Wu, Acta SCI. Circum., 2016, 9, 3400-3408 (Chinese).

[33] J. H. Li, J. J. Chen, R. Ke, C. K. Luo, J. M. Hao, Catal. Commun., 2007, 8, 1896-1900.

[34] S. Beran, B. Wichterlova, H. G. Karge, J. Chem. Soc. Faraday Trans., 1990, 86, 3033-3037.

[35] J. Thoret, P. P. Man, P. Ngokoli-Kekele, J. Fraissard, Microporous Mesoporous Mater., 2001, 49, 45-56.

[36] H. Pérez, P. Navarro, J. J. Delgado, M. Montes, Appl. Cata. A, 2011, 400, 238-248.

[37] T. Boningari, P. R. Ettireddy, A. Somogyvari, Y. Liu, A. Vorontsov, C. A. McDonald, P. G. Smirniotis, J. Catal., 2015, 325, 145-155.

[38] G. Gao, J. W. Shi, C. Liu, C. Gao, Z. Y. Fan, C. M. Niu, Appl. Surf. Sci., 2017, 411, 338-346.

[39] Z. B. Wu, R. B. Jin, Y. Liu, H. Q. Wang, Catal. Commun., 2008, 9, 2217-2220.

[40] Y. P. Wan, W. R. Zhao, Y. Tang, L. Li, H. J. Wang, Y. L. Cui, J. L. Gu, Y. S. Li, J. L. Shi, Appl. Catal. B, 2014, 148-149, 114-122.

[41] K. H. Park, S. M. Lee, S. S. Kim, D. W. Kwon, S. C. Hong, Catal. Lett., 2013, 143, 246-253.

[42] H. W. Nesbitt, D. Banderjee, Am. Mineral., 1998, 83, 305-315.

[43] National Institute of Standards and Technology (NIST). X-ray Photoelectron Spectroscopy Database. Accessed on April 10, 2017, http://strdata.nist.gov/xps.

[44] Z. Y. Ding, L. X. Li, D. Wade, E. F. Gloyna, Ind. Eng. Chem. Res., 1998, $37,1707-1716$. 
[45] J. H. Chen, M. Q. Shen, X. Q. Wang, G. S. Qi, J. Wang, W. Li, Appl. Catal. B, 2013, 134-135, 251-257.

[46] P. Sun, R. T. Guo, S. M. Liu, S. X. Wang, W. G. Pan, M. Y. Li, Appl.
Catal. A, 2017, 531, 129-138.

[47] C. L. Yu, B. C. Huang, L. F. Dong, F. Chen, Y. Yang, Y. M. Fan, Y. X. Yang, X. Q. Liu, X. N. Wang, Chem. Eng. J., 2017, 316, 1059-1068.

\title{
Mn/beta与Mn/ZSM-5催化剂对氨选择性催化还原NO的 低温催化活性比较: 锰前驱体的影响
}

\author{
许文晋 ${ }^{\mathrm{a}}$, 张光旭 ${ }^{\mathrm{a},{ }^{*}}$, 陈晗炜 ${ }^{\mathrm{a}}$, 张国孟 ${ }^{\mathrm{b}}$, 韩 洋 ${ }^{\mathrm{a}}$, 常意川 ${ }^{\mathrm{a}}$, 龚 鹏 $^{\mathrm{a}}$ \\ a武汉理工大学化学化工与生命科学学院, 湖北武汉 430070 \\ ' 上海亨远船舶设备有限公司, 上海201709
}

\begin{abstract}
摘要: 氮氧化物 $\left(\mathrm{NO}_{x}\right)$ 作为主要的大气污染物之一, 给环境和人类带来一定危害, 其主要源于汽车、轮船以及工厂中液态(汽 油和柴油)或固态(煤)化石原料的燃烧. 目前, 选择性催化还原法(SCR)因技术相对成熟且经济有效, 被广泛应用于氮氧化 物脱除. 催化剂是该技术的关键, 而典型的商业钒系催化剂 $\left(\mathrm{V}_{2} \mathrm{O}_{5}-\mathrm{WO}_{3} / \mathrm{TiO}_{2}\right.$ 和 $\left.\mathrm{V}_{2} \mathrm{O}_{5}-\mathrm{MoO}_{3} / \mathrm{TiO}_{2}\right)$ 存在工作窗口温度窄 (300-400 $\left.{ }^{\circ} \mathrm{C}\right) 、 \mathrm{~V}_{2} \mathrm{O}_{5}$ 的生物毒性以及较高的 $\mathrm{SO}_{2}$ 氧化性能等缺点, 因此开展高效且环境友好催化剂的研究工作迫在眉睫.

近年来, 锰基催化剂因其丰富的价态变化以及氧化形态而受到科研工作者的广泛关注. 研究者已经对锰前驱体做了 大量研究, 但是关于不同锰前驱体制备得到的催化剂的活性物种组成以及催化活性往往存在着不同观点. 因此进一步开 展对锰前驱体研究仍有必要. 同时, 二氧化钣载体比表面积较小, 并不是制备锰基催化剂的理想载体. 分子篎载体因其比 表面积大、特殊的孔道结构以及丰富的酸位等特点引起了研究者的关注. 用于制备锰基催化剂的分子篮载体主要有 ZSM-5, Beta, USY和SAPO等, 其中ZSM-5系列催化剂是研究热点. 另一方面, 研究发现Beta分子篮具有良好的水热稳定性, 被认为是理想的 $\mathrm{NH}_{3}$-SCR催化剂载体. 研究者对比了不同金属负载的Beta分子篮与ZSM-5分子篮的催化活性, 结果表明, Fe/beta的催化活性高于Fe/ZSM-5和Fe/ZSM-11; Cu/beta的催化活性与Cu/ZSM-5相当, 均表现出较高的活性. 而关于 Mn/ZSM-5的研究已有大量文献报道, 但关于 Mn/beta的研究相对较少. 另外, 关于不同锰前驱体在Beta以及ZSM-5分子篮 载体表面的物化性质差异也少有报道.
\end{abstract}

本文以H/beta和H/ZSM-5分子篮作为载体, 采用硝酸锰、乙酸锰和氯化锰三种前驱体, 通过湿法浸渍制备了 $\mathrm{Mn} / \mathrm{beta}$ 和 Mn/ZSM-5两类 $\mathrm{NH}_{3}$-SCR 催化剂, 并在固定床管式反应器中对比评价了两类催化剂的催化活性. 凭借氮气等温吸附/脱附 $(B E T) 、 X$ 射线衍射 $(X R D) 、 X$ 射线荧光 $(X R F)$ 、氢气程序升温还原 $\left(\mathrm{H}_{2}-\mathrm{TPR}\right)$ 、氨气程序升温脱附 $\left(\mathrm{NH}_{3}-\mathrm{TPD}\right)$ 以及 $X$ 射线光电 子能谱(XPS)等技术对催化剂进行了表征, 系统分析了不同前驱体在两种载体表面形成的活性组分以及理化性质对催化性 能的影响.

催化剂活性评价结果表明, 对于 $\mathrm{Mn} / \mathrm{beta}$ 和Mn/ZSM-5催化剂, 在220-350 ${ }^{\circ} \mathrm{C}$ 反应温度区间内, 乙酸锰和硝酸锰制备的催 化剂 $\mathrm{NO}$ 脱除率均在 $80 \%$ 以上. 其中 $\mathrm{Mn} /$ beta-Ac在 $240{ }^{\circ} \mathrm{C}$ 时达到最高的 $\mathrm{NO}$ 脱除率 $97.5 \%$, 并且在 $220-350{ }^{\circ} \mathrm{C}$ 温度区间内保持 着 $90 \%$ 以上的活性, 具有最宽的活性温度窗口. 同时, 在两系列锰基催化剂中, 乙酸锰制备的催化剂均表现出最佳的催化活 性, 且对于同一种前驱体制备的催化剂, Mn/beta催化剂的 $\mathrm{NH}_{3}$-SCR 活性优于Mn/ZSM-5. BET数据显示, 负载镇物种之后, 催化剂的比表面积和孔体积均明显减小, 但相对于Mn/ZSM-5催化剂, Mn/beta催化剂仍保持着优良的织构性质. XRD、XRF 及 $\mathrm{H}_{2}$-TPR结果表明, 氯化锰前驱体主要产生少量的结晶 $\mathrm{Mn}_{3} \mathrm{O}_{4}$ 并且大部分保持以 $\mathrm{MnCl}_{2}$ 的形式存在, 这也是此类催化剂表 现出较差的低温催化活性的原因. 结合XPS表征分析了催化剂的表面性质. 结果表明, 硝酸锰前驱体主要产生结晶 $\mathrm{MnO}_{2}$ 和少量未分解的硝酸锰, 乙酸锰前驱体主要产生高度分散的无定形 $\mathrm{MnO}_{2}$ 和 $\mathrm{Mn}_{2} \mathrm{O}_{3}$ 混合物以及结晶 $\mathrm{Mn}_{3} \mathrm{O}_{4}$. 进一步结合 $\mathrm{NH}_{3}$-TPD分析结果以及活性评价结果可以得出: 丰富的无定形 $\mathrm{MnO}_{x}\left(\mathrm{MnO}_{2}\right.$ 和 $\left.\mathrm{Mn}_{2} \mathrm{O}_{3}\right)$ 物种、较高的表面锰含量和表面活性 氧基团以及适当含量的弱酸位有利于提升催化剂的低温 $\mathrm{NH}_{3}$-SCR催化活性.

关键词: Mn/beta; Mn/ZSM-5; 低温; 催化性能; 选择性催化还原; 锰前驱体

收稿日期: 2017-08-15. 接受日期: 2017-11-22. 出版日期: 2018-01-05.

*通讯联系人。电话: 13871467069; 电子信箱: zhanggx2002@163.com

基金来源：国家重点研发计划(CDGC01-KT16).

本文的电子版全文由Elsevier出版社在ScienceDirect上出版(http://www.sciencedirect.com/science/journal/18722067). 